\title{
Journal of Financial
}

and Quantitative Analysis

\section{DECEMBER 1969}

The Aggregation of Investor's Diverse Judgments and

Preferences in Purely Competitive Security Markets

John Lintner

Risk Disposition and the Separation

Property in Portfolio Selection

Nils H. Hakansson

Risk-Refurn Measurement in Portfolio Selection and

Performance Appraisal Models: Progress Report

Richard S. Bower and Donald F. Wippern

Risk-Return Measures of Ex Post Portfolio Performance

Keith V. Smith and Dennis A. Tito

Risk, Ruin and Investment Analysis

Robert E. Machol and Eugene M. Lerner

On the Risk-Return Trade-Off in the Valuation of Assets Michael Adler

Risk and the Value of Securities

Alexander A. Robichek

The University of Washington

Graduate School of Business Administration

and the

WESTERN FINANCE ASSOCIATION 
JOURNAL OF FINANCIAL AND RUANTITATIVE ANALYSIS

VOLUME IV, NUMBER 4, DECEMBER, 1969

THE AGGREGATION OF INVESTOR'S DIVERSE JUDGMENTS

AND PREFERENCES IN PURELY COMPETITIVE

SECURITY MARKETS . . . . . . . . . . . . . . . . 347

John Lintner

RISK DISPOSITION AND THE SEPARATION PROPERTY IN

PORTFOLIO SELECTION . . . . . . . . . . . . . . . 401

Nils $H$. Hakansson

RISK-RETURN MEASUREMENT IN PORTFOLIO SELECTION

AND PERFORMANCE APPRAISAL MODELS: PROGRESS

REPORT . . . . . . . . . . . . . . . . . . . . . . . 417

Richard $S$. Bower and Ronald $F$. Wippern

RISK-RETURN MEASURES OF EX POST PORTFOLIO

PERFORMANCE ....................... 449

Keith V. Smith and Dennis A. Tito

RISK, RUIN AND INVESTMENT ANALYSIS . . . . . . . . . . . . . 473

Robert E. Machol and Eugene M. Lerner

ON THE RISK-RETURN TRADE-OFF IN THE VALUATION

OF ASSETS . . . . . . . . . . . . . . . . . . . . 493

Michael Adler

RISK AND THE VALUE OF SECURITIES . . . . . . . . . . . . 513 A Lexander A. Robichek

ANNOUNCEMENTS: DECEMBER 1970 SPECIAL ISSUE . . . . . . . . . 539

WESTERN FINANCE ASSOCIATION MEETINGS ...... . 540

The views and opinions expressed are those of the authors and do not necessarily reflect those of the Graduate School of Business Administration of the University of Washington or of the Western Finance Association.

(Copyright 1970 by the Graduate School of Business Administration, University of Washington.) 


\section{JOURNAL OF FINANCIAL AND QUANTITATIVE ANALYSIS \\ GRADUATE SCHOOL OF BUSINESS ADMINISTRATION, UNIVERSITY OF WASHINGTON, SEATTLE, WASHINGTON 98105}

EDITORIAL STAFF

Charles A. D'Ambrosio, Managing Editor

Charles W. Haley, Associate Managing Editor

Lillian Ashworth, Editorial Assistant

BOARD OF EDITORS

Fred P. Morrisey
Charles A. D'Ambrosio

J. Fred Weston

Ezra Solomon

\section{ASSOCIATE EDITORS}

William W. Alberts, Washington

Marshall E. Blume, Pennsylvania

Charles P. Bonini, Stanford

Myles Delano, Michigan State

Thomas R. Dyckman, Cornell

Robert C. Goshay, UC, Berkeley

Frederick S. Hammer, FDIC

Austin C. Hoggatt, UC, Berkeley

James R. Jackson, UC, Los Angeles

James C. T. Mao, British Columbia

Jacob B. Michaelsen, UC, Santa Cruz

Alfred N. Page, Washington

Richard Roll, Carnegie-Mellon

R. Haney Scott, Washington

William F. Sharpe, UC, Irvine

Keith V. Smith, UC, Los Angeles

James Van Horne, Stanford

Raymond J. Jessen, UC, Los Angeles Donald Woods, UC, Los Angeles

The JOURNAL OF FINANCIAL AND QUANTITATIVE ANALYSIS is published in January, March, June, September, and December by the Graduate School of Business Administration of the University of Washington in conjunction with the Western Finance Association. The December issue is a Special, devoted to one topic of interest to the JFQA's readership. The January issue contains selected papers, discussants' comments, and Proceedings of the Western Finance Association meetings.

Membership in the Western Finance Association is available at $\$ 7.00$ per year and includes the JOURNAL subscription. Applications and information concerning membership should be addressed to Virginia McKemie-Belt, Western Finance Association, California State College at Long Beach, Long Beach, California 90804. Make checks payable to the Western Finance Association.

The annual subscription rate for individual nonmembers is $\$ 7.00$; for firms or libraries the annual rate is $\$ 10.00$. Single copies are $\$ 2.50$, except the Special issues, the price of which is $\$ 3.00$. Manuscripts and editorial correspondence should be sent to the Managing Editor. Advertising inquiries and books for review should be addressed to the Associate Managing Editor. 